\title{
ESCENAS DOCUMENTALES
}

\section{SANTIAGO, $00161-3.6 .80$}

VISTO :

Lo dispuesto en los artículos 18 y siguientes del Decre to de Rectoría $\mathrm{N}^{\circ} 448$ de 1975.

CONSIDERANDO :

Que consta en autos que la inculpada sefiorita María An gel ica Daskalakis Riquelme, ha dejado de pertenecer a esta Cor poración, según Decreto de Renuncia No 3342 de fecha 4 de marzo del presente año.

SE RESUELVE :

Se revoca el fallo consultado.

Se sobresée a la señorita María Angélica Daskalakis Riquelme, por no ser funcionaria de esta Casa de Estudios.

\section{Registrese y comuniquese.}

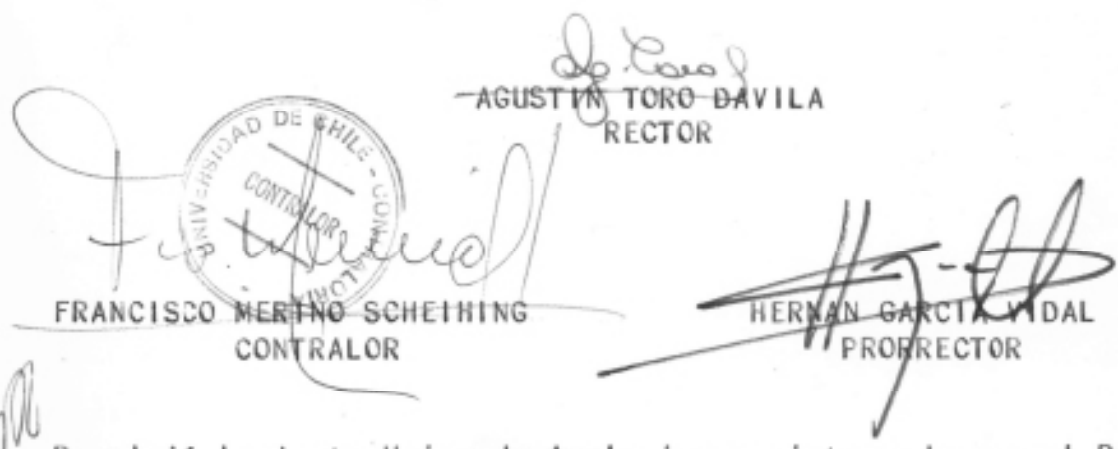

Resolvis la Junta Unica de Apelaciones, integrada por el Rector don Agustín Toro Dávila, por el Prorrector don Hernán García Ví dal y por el Contralor don Francisco Merino Scheihing.

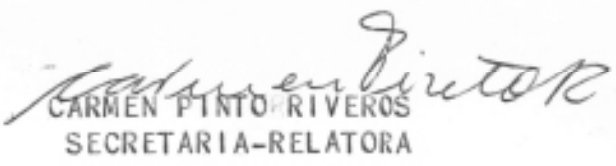

